\title{
Status of Brown Leaf Spot of Paddy in Cauvery Command Areas of Mandya District, Karnataka, India
}

\author{
C. Channakeshava* and N.S. Pankaja
}

Department of Plant Pathology, College of Agriculture, V.C. Farm, Mandya-571405, India

*Corresponding author

\section{A B S T R A C T}

Roving survey was conducted to record the disease severity of brown leaf spot of rice during kharif 2015 in paddy growing Cauvery command areas like Mandya, Srirangapatna,

\section{Keywords}

Paddy, Brown leaf spot, Disease severity and Cauvery command area

Article Info

Accepted:

12 March 2019

Available Online:

10 April 2019
Krishnarajapete, Pandavapura, Maddur and Malavalli. Disease scoring was done by employing SES scale developed by IRRI in 1996.The symptoms in the field were recognized by the greyish brown spots. On leaves, typical spots are brown in color with grey to whitish center, cylindrical to oval in shape resembling sesame seed, usually with yellow halo, while young spots are small, circular and appear as dark brown to purplish brown dots. The results revealed that the disease was prevalent in all the paddy growing areas of Mandya. In 6 taluks of Cauvery command areas surveyed the disease severity, ranged from 7.91 to 16.88 per cent. However highest average disease severity was recorded in Mandya taluk with 16.88 per cent followed by Malavalli taluk with 14.65 per cent. Lowest average disease severity was recorded in Maddur taluk (7.91\%) followed by Srirangapatna taluk with 8.02 per cent. Among the villages surveyed average highest per cent disease severity was recorded in Holalu with 21.21 per cent followed by Mallanaya kanakatte with19.77 per cent and Hulikere with 18.10 per cent of Mandyataluk. However lowest average disease severity was recorded in Sannakothannuru and Melukote villages with 4.44 per cent followed by Konanahalli village (5.35 \%) of Pandavapurataluk.

\section{Introduction}

Rice is the second largest crop grown in the world in terms of both area and production and it is the staple food for more than half of world's population. However over 90 percent of the rice in the world is produced and consumed in Asian countries. Karnataka has made rapid progress in rice cultivation during the last few years. Mandya, Uttar Kannada, Mysuru, Raichur and Kodagu are the main producers. It is grown in all the three seasons viz., kharif, rabi and summer under rainfed and irrigated conditions. One of the major constraints of rice production is that the crop is prone to many diseases caused by fungi, bacteria, nematode, virus and phytoplasma.

There are about 40 diseases reported on rice to be caused by fungi and bacteria in India. Among these diseases, brown leaf spot caused by Bipolarisoryzae has been reported to occur in all rice growing regions of India (Gangopadhyaya, 1983 and $\mathrm{Ou}, 1985$ ) since 
its first report from Madras in 1919 by Sundraraman.

The disease is of great importance in several countries and has been reported to cause enormous loss in grain yield (upto 90\%) particularly when leaf spotting phase assumes epiphytotic proportions as observed in Great Bengal Famine during 1942 (Ghose et al., 1960). The disease especially occurs in environment where water supply is scarce combined with nutritional imbalance particularly lack of nitrogen (Baranwal et al., 2013). An extensive survey was conducted during kharif season of 2012 and 2013 in major rice growing areas of Bihar to record the disease incidence of brown spot of paddy by Kumari et al., (2015).

They reported that the disease was prevelent at all the locations surveyed. Further, the disease incidence percentage varied from 15.30 to 52.10 per cent. Maximum disease incidence $(52.10 \%)$ was recorded from Samastipur. As Mandya is known for its tradition in growing padday under prolonged water logged condition, information on brown leaf spot disease is very meagre. Keeping this in view, a roving survey was conducted to record the disease severity of brown leaf spot of rice during kharif2015-16 in paddy growing Cauvery command areas.

\section{Materials and Methods}

A roving survey for the disease severity of brown leaf spot disease of paddy was undertaken during kharif 2015 in the farmer's fields of Cauvery command areas like Mandya, Srirangapatna, Krishnarajapete, Pandavapur, Madduru and Malavalli taluks. Information regarding places visited, disease severity, stage of the crop and varieties grown were recorded and are presented in the Table 2. In each village 5 paddy fields were randomly selected. In each field 50 plants were randomly scored for the disease using
SES scale developed by IRRI (1996) (Table 1).

The disease severity was calculated using below mentioned formula by Mckinney (1923).

$\mathrm{PDI}=$

$$
\frac{0(\mathrm{X} 0)+1(\mathrm{X} 1)+2(\mathrm{X} 2)+\ldots \ldots+\mathrm{n}(\mathrm{Xn}) * 100}{\mathrm{X} 0+\mathrm{X} 1+\mathrm{X} 2+.+\mathrm{Xn} * \text { maximum grade }}
$$

Where,

$0,1,2, \mathrm{n}=$ score

$\mathrm{X} 0, \mathrm{X} 1, \mathrm{X} 2, \mathrm{Xn}=$ number of entries or

$P D I=\frac{\text { Sum of total numericals }}{\text { Total No.of plants observed }} \times \frac{1}{\text { maximum scale }} \times 100$

\section{Results and Discussion}

A roving survey for the disease severity of brown leaf spot disease of paddy was undertaken during kharif2015 in the farmer's fields of Cauvery command areas like Mandya, Srirangapatna, Krishnarajapete, Pandavapur, Madduru and Malavalli taluks. The symptoms in the field were recognized by the greyish brown spots. On leaves, typical spots are brown in color with grey to whitish center, cylindrical to oval in shape resembling sesame seed, usually with yellow halo, while young spots are small, circular and appear as dark brown to purplish brown dots (Plate 1).

The results revealed that the brown leaf spot disease of paddy was prevalent in all the paddy growing areas of Mandya.In 6 taluks of Cauvery command areas surveyed the disease severity, ranged from 7.91 to 16.88 per cent. In most of the cases the crop was grown under flooded conditions. The average disease severities recorded in different villages of each taluks are as follows.

Total of 15 villages were surveyed for disease severity of brown leaf spot disease in Mandya 
taluk. Among the villages highest per cent disease severity of 21.21 per cent was recorded in Holalu village followed by Kannahatti village (20.33\%), Mallanaya kanakatte village (19.77\%) and Panakanahalli village (18.44\%). It was observed that lowest disease severity was recorded in Ganadalu village $(12.22 \%)$ followed by Madala village (12.65\%). However the average per cent disease severity in Mandya taluk was 16.88 per cent.

In Maddur taluk average per cent disease severity recorded was 7.19 per cent. A total of 5 villages were surveyed for the disease severity. Highest per cent disease severity was recorded in Shivapura village with 10.08 per cent followed by Chamanahalli village with 9.99 per cent and Madduru (9.32\%). The lowest disease severity was recorded in Bharathinagara village $(4.88 \%)$ followed by Dashanahalli village (5.32\%).

Total of 14 villages were surveyed for the disease severity brown leaf spot disease in Pandavapura taluk. Highest per cent disease severity was recorded in Ganadahosur village $(16.21 \%)$ followed by Bolenahalli village (15.33\%), Dinkadakaval village (13.99\%) and Kyathanahalli village (13.55\%). Lowest disease severity was recorded in Sankothannuru and Melukote villages (4.44\%). However $10.42 \%$ average disease severity was recorded in Pandavapura taluk.

Total of 6 villages were surveyed for the disease severity of brown leaf spot disease in Malavalli taluk. Among the villages, the highest per cent disease severity was recorded in Malavalli village (16.77\%) followed by Maganuru village $(16.44 \%)$ and Thammanahalli village (15.55\%). The lowest disease severity was recorded in Bandure $(11.33 \%)$ and the average per cent disease severity of $14.65 \%$ was recorded in Malavalli taluk.
In Krishnarajapete $11.58 \%$ average per cent disease severity was recorded. A total of 6 villages were surveyed for the disease severity in Krishnarajapete taluk. Highest per cent disease severity was recorded in Hosaholalu village (11.99\%) followed by Machanahalli village (10.88\%) and Krishnarajapete (10.66\%). Lowest disease severity was recorded in Alambadi village $(6.54 \%)$

Total of 7 villages were surveyed for the disease severity of brown leaf spot in Srirangapatna taluk. Highest per cent disease severity was recorded in Naguvanahalli and Melapur villages $(8.88 \%)$ followed by Darasaguppe village (7.78\%) and Gumbaz village $(7.76 \%)$. Lowest disease severity was recorded in Neralakere village $(6.24 \%)$. The average per cent disease severity of $8.02 \%$ was recorded in Srirangapatna taluk.

Thus from among the taluks surveyed, the results revealed that highest average disease severity was recorded in Mandya taluk with 16.88 per cent followed by Malavalli taluk with 14.65 per cent and Krishnarajapete taluk 11.58 per cent. Lowest average disease severity was recorded in Maddur taluk (7.91\%) followed by Srirangapattanataluk with 8.02 per cent.

The villages surveyed average highest per cent disease severity was recorded in Holalu village with 21.21 per cent followed by Mallanayakanakatte village with 19.77 per cent, Soudenahalli village with 18.55 per cent and Hulikere village with 18.10 per cent of Mandya taluk. However lowest average disease severity was recorded in Sannakothannuru and Melukote villages with 4.44 per cent followed by Konanahalli village with 5.35 per cent and Narayanapura village with 5.45 per cent of Pandavapura taluk. 
Table.1 Standard evaluation system scale for brown leaf spot disease of paddy

\begin{tabular}{|c|l|}
\hline Score & Description \\
\hline 0 & No disease observed \\
\hline 1 & Less than $1 \%$ \\
\hline 2 & $1-3 \%$ \\
\hline 3 & $4-5 \%$ \\
\hline 4 & $6-10 \%$ \\
\hline 5 & $11-15 \%$ \\
\hline 6 & $16-25 \%$ \\
\hline 7 & $26-50 \%$ \\
\hline 8 & $51-75 \%$ \\
\hline 9 & $76-100 \%$ \\
\hline
\end{tabular}

Table.2 Survey for the disease severity of brown leaf spot of paddy in Cauvery command areas of Mandya district, Karnataka

\begin{tabular}{|c|c|c|c|c|c|}
\hline Taluks & Villages & Variety & $\begin{array}{l}\text { Age of the } \\
\text { crop (Days) }\end{array}$ & $\begin{array}{c}\text { Average } \\
\text { disease } \\
\text { severity }(\%)\end{array}$ & $\begin{array}{c}\text { Mean disease } \\
\text { severity of } \\
\text { Taluks }(\%)\end{array}$ \\
\hline \multirow{15}{*}{ 1.Mandya } & Dudda & Akshaya & 85 & 15.54 & \multirow{15}{*}{16.88} \\
\hline & Kannahatti & $\begin{array}{c}\text { MTU- } \\
1001\end{array}$ & 92 & 20.33 & \\
\hline & Shivalli & Jaya & 95 & 13.35 & \\
\hline & Soudenahalli & $\begin{array}{c}\text { MTU- } \\
1001 \\
\end{array}$ & 75 & 18.55 & \\
\hline & Madala & Thanu & 98 & 12.65 & \\
\hline & Hadya & Thanu & 120 & 16.78 & \\
\hline & Hulikere & BR-2655 & 125 & 18.10 & \\
\hline & V. C. Farm & IR-64 & 90 & 16.88 & \\
\hline & Ganadalu & $\begin{array}{c}\text { DRH- } \\
836\end{array}$ & 85 & 12.22 & \\
\hline & Modachakanahalli & MC-13 & 80 & 17.33 & \\
\hline & Chandagala & IR-64 & 90 & 14.24 & \\
\hline & Mallanayakanakatte & $\begin{array}{c}\text { Advanta- } \\
837\end{array}$ & 90 & 19.77 & \\
\hline & Holalu & Jaya & 85 & 21.21 & \\
\hline & Panakanahalli & MC-13 & 92 & 18.44 & \\
\hline & Mandya & Akshaya & 85 & 17.65 & \\
\hline \multirow{3}{*}{ 2.Maddur } & Maddur & $\begin{array}{c}\text { MTU- } \\
1001\end{array}$ & 75 & 9.32 & \multirow{3}{*}{7.91} \\
\hline & Shivapura & Thanu & 75 & 10.08 & \\
\hline & Chamanahalli & $\begin{array}{c}\text { MTU- } \\
1001\end{array}$ & 84 & 9.99 & \\
\hline
\end{tabular}




\begin{tabular}{|c|c|c|c|c|c|}
\hline & Dashahalli & Jaya & 65 & 5.32 & \\
\hline & Barathinagara & Siri & 85 & 4.88 & \multirow{7}{*}{14.65} \\
\hline \multirow{6}{*}{ 3.Malavalli } & Malavalli & Thanu & 90 & 16.77 & \\
\hline & Kagepura & $\begin{array}{l}\text { Super } \\
\text { haman }\end{array}$ & 95 & 12.99 & \\
\hline & Thammanahalli & $\begin{array}{l}\text { Super } \\
\text { haman }\end{array}$ & 95 & 15.55 & \\
\hline & Maganuru & Siri & 95 & 16.44 & \\
\hline & Shettihali & Jaya & 90 & 14.77 & \\
\hline & Bandure & Siri & 92 & 11.33 & \\
\hline \multirow{7}{*}{ 4.Srirangapattana } & Srirangapattana & RASI & 105 & 8.21 & \multirow{7}{*}{8.02} \\
\hline & Baburayanakoppalu & RASI & 98 & 8.43 & \\
\hline & Gumbaz & $\begin{array}{l}\text { MTU } \\
1001\end{array}$ & 90 & 7.76 & \\
\hline & Melapura & Jaya & 130 & 8.88 & \\
\hline & Darasadappe & $\begin{array}{l}\text { MTU- } \\
1001\end{array}$ & 97 & 7.78 & \\
\hline & Naguvnahalli & Mangala & 76 & 8.88 & \\
\hline & Neralakere & $\begin{array}{l}\text { IET- } \\
7575\end{array}$ & 85 & 6.24 & \\
\hline \multirow{14}{*}{ 5.Pandavapura } & Dinkadakaval & IR-20 & 92 & 13.99 & \multirow{14}{*}{10.42} \\
\hline & Ganadahosure & $\begin{array}{c}\text { MTU- } \\
1001\end{array}$ & 105 & 16.21 & \\
\hline & Bolenahalli & Jaya & 85 & 15.33 & \\
\hline & Jakkanahalli & $\begin{array}{l}\text { DRH- } \\
836\end{array}$ & 86 & 13.55 & \\
\hline & Hiremarali & MC-13 & 65 & 12.44 & \\
\hline & Amrutheswarahalli & $\begin{array}{l}\text { DRH- } \\
836\end{array}$ & 79 & 13.33 & \\
\hline & Kyathanahalli & RASI & 95 & 13.55 & \\
\hline & Thirumalapura & $\begin{array}{c}\text { IR- } \\
30864\end{array}$ & 98 & 9.55 & \\
\hline & Konanahalli & Mangala & 86 & 5.32 & \\
\hline & Sonkathonnuru & $\begin{array}{l}\text { MTU- } \\
1001\end{array}$ & 90 & 4.44 & \\
\hline & Nallahalli & Jaya & 89 & 9.65 & \\
\hline & Hulikerekoppalu & Jaya & 80 & 8.75 & \\
\hline & Melukote & Jaya & 92 & 4.44 & \\
\hline & Narayanapura & Jaya & 98 & 5.45 & \\
\hline \multirow{6}{*}{ 6.Krishnarajapete } & Krishnarajapete & Prakash & 135 & 10.66 & \multirow{6}{*}{11.58} \\
\hline & Machanahalli & Prakash & 85 & 10.88 & \\
\hline & Kikkeri & Thanu & 90 & 9.10 & \\
\hline & Hosaholalu & Thanu & 95 & 11.99 & \\
\hline & Akkihebalu & BR-2655 & 85 & 8.76 & \\
\hline & Alambadi & Thanu & 94 & 6.54 & \\
\hline
\end{tabular}


Plate.1 Survey for the disease severity of brown leaf spot of paddy in Mandya district
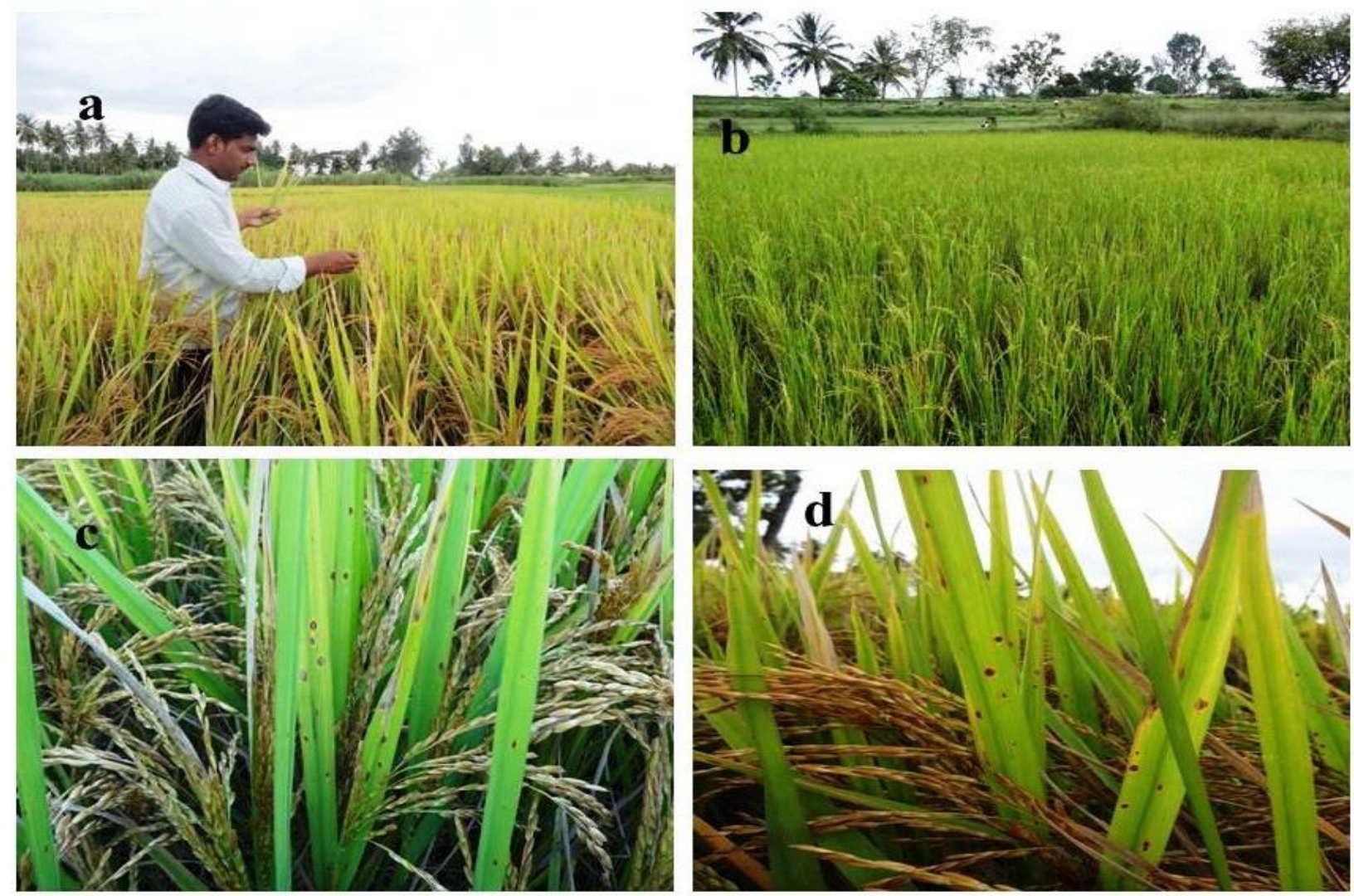

a) Survey field holalu village (Mandya, Tq)

b) Survey field in Pandavapura(Tq)

c) Survey field in Banduru village (Malavalli, Tq)

d) Survey field in Shivapura village (Maddur, Tq)

Further it was observed that, the crop was susceptible at later part of growth stages which is evident in susceptible check MTU1001, wherein maximum disease severity was observed at 92 DAP (20.33\%) when compared to 57 DAP (9.32\%) at Mandya taluk. Similarly at 105 DAP $(16.5 \%)$ when compared to 90 DAP (4.44\%) at Pandavapura taluk (Table 2).

The results obtained on the survey for the disease severity of the brown leaf spot disease indicated that the disease was prevalent in all the paddy growing areas surveyed during kharif2015. Total of 6 taluks of Cauvery command areas were surveyed for the disease severity. Among the six taluks surveyed, highest average per cent disease severity was recorded in Mandya taluk (16.88\%) followed

by Malavalli taluk with 14.65 per cent and Krishnarajapete taluk with 11.58 per cent. Lowest average disease severity was recorded in Maddur taluk (7.91\%) followed by Srirangapattana taluk with 8.02 per cent. Similar results were recorded by Gupta et al., (2013) wherein they reported that there was high disease severity of 37.13 per cent during kharif2011 to 2012 in major rice growing areas of Jammu sub-tropics. Kumari et al., (2015) also found disease incidence varying from 15.30 to 52.10 per cent, during Kharif season of 2012 and 2013 in major rice growing areas of Bihar. During the present study the results revealed that, the average disease severity varied from one taluk to another taluk where, the range being 7.91 to 16.88 per cent from among the 6 taluks surveyed. 


\section{References}

Anonymous, Standard evaluation system for rice (4thed.). Manila, Philippine: IIRI, 1996.

Baranwal, MK, Kotasthane A, Magculia N., Mukherjee PK, Savary S., Sharma AK, Singh HB, Singh US, Sparks AH, Variar M., Zaidi N., A review on crop losses, epidemiology and disease management of rice brown spot to identify research priorities and knowledge gaps. European J. Pl. Pathol.2013; 136:443-457.

Gangopadhyay, S., Current concepts on fungal diseases of rice. Today and tomorrow's Printers and Publishers, New Delhi, 1983, 349.

Ghose, RLM., Ghatge MB, Subramanian V.Rice in India (revised edn.) ICAR, New Delhi, 1960, 474.

Gupta, V., Shamas N., Razad VK., Sharma
BC., Sharma R., Kaur K., Singh I., John D., Kumar A. Foliar application of fungicides for the management of brown spot disease in rice (Oryza sativa L.) caused by Bipolarisoryzae. African J. Agric. Res.2013; 8(25): 3503-3309.

Kumari S., Kumar A, Rani S. Morphological characterization of Bipolarisoryzae causing brown spot of paddy in Bihar. Int. Educ. Res. J.2015; 1(5):85-87.

Mckinney, HH., A new system of grading of plant diseases. J. Agric. Res. 1923; 26:195-218.

$\mathrm{Ou}$, SH., Rice disease 2nd edn. Kew, Commonwealth Mycological Institute. 1985,380 .

Sundraraman, S., Helminthosporium disease of rice. Bull. Res. Inst. Pusa, 1919, 128:1-7.

\section{How to cite this article:}

Channakeshava, C. and Pankaja, N.S. 2019. Status of Brown Leaf Spot of Paddy in Cauvery Command Areas of Mandya District, Karnataka, India. Int.J.Curr.Microbiol.App.Sci. 8(04): 1654-1660. doi: https://doi.org/10.20546/ijcmas.2019.804.193 